REGULAR ARTiCLE

\title{
INFLUENCE OF WEATHER FACTORS ON INCIDENCE OF SHOOT AND FRUIT BORER (EARIAS VITTELLA FABIRICUS) ON BHENDI
}

\author{
K. ARCHUNAN* ${ }^{*}$ M. PAZHANISAMY, S. SATHYA \\ Department of Entomology, Faculty of Agriculture, Annamalai University, \\ Annamalai Nagar 608 o02, Tamil Nadu, India
}

\begin{abstract}
The field experiments were carried out in the farmer field at C. Mutlur near Chidambaram during rabi and kharif 2017. The results of experiments revealed that the per cent shoot damage and fruit damage by E. vittella on bhendi reached peak on $13^{\text {th }}$ and $15^{\text {th }} \mathrm{MSW}$ in rabi season, whereas $43^{\text {rd }}$ and $42^{\text {nd }} \mathrm{MSW}$ in kharif season. The per cent shoot damage and fruit damage by $E$. vittella were exerted significantly positively correlated with minimum (0.552 and 0.698) and maximum temperature (o.629 and 0.748 ), whereas rainfall positively correlated with per cent shoot and fruit damage but it was non significant (o.111 and 0.297), however relative humidity (-0.178 and-0.210) and sunshine hours were exerted negatively correlated with per cent shoot damage and fruit damage by $E$. vittella during rabi 2017. The kharif season 2017 indicated that per cent shoot damage and fruit damage of bhendi was positively non significant association with RH and rain fall, while negatively non significant correlation with minimum temperature (-0.43 and-0.309) and sunshine hours (-0.265 and-0.283) was recorded.
\end{abstract}

Keywords: Shoot damage and fruit damage, E. vittella, weather parameter, meterological standard weeks, correlation, regression.

\section{INTRODUCTION}

Bhendi Abelmoschus esculentus L. (Moench) (Family: Malvaceaeo, is an economically significant crop cultivated in India and is used all over the world as vegetable [1]. It is commonly known as okra or lady's finger and the origin of bhendi is Africa. In India ranks first in the world with $5,784.0$ thousand tones $(72 \%$ of the total world production) of bhendi [2]. In Tamilnadu the crop occupies 11000 ha with the productivity of 75.4 thousand tones $\mathrm{mt}$ $\mathrm{ha}^{-1}$ in the state [3]. It being a short duration crop and though bhendi is widely cultivated season such as February-March, June-July and October-November. The major insect pests known to attack bhendi in India are leaf hopper, aphid, white fly, spider mite and fruit borer, which are importance in bhendi [4]. Among them, shoot and fruit borer, Earias vittella (Fabricius) considered major pest which cause severe damage to crop and causing more than $50 \%$ loss in cotton and $69 \%$ on bhendi alone in various parts of India. The E. vittella alone cause upto 41.6 per cent net yield loss in bhendi [5]. The aim of this study was to determine the role of meteorological factors on incidence of $E$. vittella on bhendi. This will facilitate to excute proper time of application of insecticides and other control strategies for the E. vittella on Bhendi.

\section{MATERIALS AND METHODS}

The field experiments were carried out in farmer field at C. Mutlur near Chidambaram during 2017. The popular cultivar of Arka anamika seeds were sown in $45 \times 30 \mathrm{~cm}$ spacing and $4 \times 5 \mathrm{~m}$ plot size during $20^{\text {th }}$ Jan (rabi 2017) and $25^{\text {th }}$ Aug (kharif 2017). Normal agronomic procedures were taken on the entire crop throughout season without plant protection measures. The pest population $E$. vittella was recorded on Bhendi in terms of per cent of damage randomly selected five plants in each replication [6]. Weather parameters like Temperature, Relative humidity, Rainfall and Sunshine hour were recorded from meteorological observatory at Annamalai University and correlated with incidence of $E$. vittella. Correlation analysis was carried out as per Gomez and Gomez [7].

\section{RESULTS AND DISCUSSION} Studies on incidence of $E$. vittella in bhendi
ecosystem during rabi and kharif season 2017

In rabi season studies on pest incidence (table 1 and Fig.1) revealed that shoot damage of $E$. vittella on bhendi was noticed from $7^{\text {th }}$ MSW (meteorological standard week) to $17^{\text {th }}$ MSW ranging from $19.64-42.27 \%$ and also fruit damage noticed from $8^{\text {th }}$ and $17^{\text {th }}$ MSW. The highest per cent shoot damage was recorded at $13^{\text {th }}$ MSW (42.27\%) followed by $14^{\text {th }}$ MSW (38.66\%) and $10^{\text {th }}$ MSW (37.10\%) and fruit damage was recorded $15^{\text {th }}$ MSW (44.47\%) followed by $11^{\text {th }}$ MSW (43.33\%).

The present finding is in concordance to Chouhan et al. [8] who showed that the incidence of $E$. vittella was observed $7^{\text {th }}$ to $16^{\text {th }}$ MSW reached peak on last week of March

Received 11 March 2018; Accepted 1 May 2018

*Corresponding Author

K. Archunan

Department of Entomology, Faculty of Agriculture, Annamalai University, Annamalai Nagar 608 oo2, Tamil Nadu, India

Email: greenwld115@gmail.com

( This article is open access and licensed under the terms of the Creative Commons Attribution License (http://creativecommons.org/licenses/by/4.o/) which permits unrestricted, use, distribution and reproduction in any medium, or format for any purpose, even commercially provided the work is properly cited. Attribution - You must give appropriate credit, provide a link to the license, and indicate if changes were made. 
(12 ${ }^{\text {th }} \mathrm{MSW}$ ) with 2 larvae/plant and the seasonal mean was 1.44 larvae/plant followed by $13^{\text {th }}$ MSW with 1.5 larvae/plant and Shivashankara [9] observed incidence commenced from $5^{\text {th }} \mathrm{MSW}$ and increased at fruit maturity stage and mean incidence peak (3.20 larvae/plant) was during $14^{\text {th }} \mathrm{MSW}$.

In kharif season per cent of shoot damage (table 1 and fig. 2) E. vittella on bhendi observed on $38^{\text {th }}$ to $48^{\text {th }} \mathrm{MSW}$ which ranged from 12.5 to $33.98 \%$ and the maximum shoot damage recorded $43^{\text {rd }}$ MSW (2.7 larvae/plant). The fruit damage noticed on $39^{\text {th }}$ to $48^{\text {th }}$ MSW that ranged from 19.33 to $42.1 \%$ and maximum fruit damage (fig. 2) noticed $43^{\text {rd }}$ followed by $42^{\text {nd }}$ and $44^{\text {th }}$ MSW. There is no damage on occur on $36^{\text {th }}$ and $37^{\text {th }}$ during kharif season 2017. The present finding is in concordance to Sharma et al. [10], who reported the peak infestation of E. vittella on bhendi was observed in $45^{\text {th }}$ standard week. The maximum number of larvae (7.5 larvae per plant) recorded in $42^{\text {nd }}$ standard week.

\section{Influence of weather parameters on per cent shoot and fruit damage by $E$. vittella on bhendi during rabi 2017}

Correlation between weather parameters and shoot damage and fruit damage of $E$. vittella in bhendi during rabi 2017 are presented in table. 2. The studies indicated that R. H ( $\mathrm{r}=-0.178$ and-0.210) exerted non significant negative association with per cent shoot damage and fruit damage of $E$. vittella respectively. The present finding is in concordance to Sharma et al. [10], in which it was observed that relative humidity was negatively correlated. Whereas sunshine hour ( $\mathrm{r}=-0.566$ and-0.641) positively correlated with shoot and fruit but it was significant. However maximum temperature $(\mathrm{r}=0.552$ and 0.698$)$ and minimum temperature $(\mathrm{r}=0.629$ and 0.748$)$ exhibited significant positive association with shoot damage and fruit damage by $E$. vittella respectively. Where rainfall $(\mathrm{r}=$ 0.111 and 0.074 ) exhibited positive association with shoot damage and fruit damage but it was non significant. Rajput and Tayde [11] showed that positively correlated with maximum temperature.

Multiple regression equations were fitted for regression analysis between the weather parameter $(\mathrm{X})$ and both the shoot damage and fruit damage on E. vittella in bhendi during the rabi season 2017.

\section{Particular regression equation}

Shoot damage $\mathrm{Y}=-310.75+4.27 \mathrm{X}_{1}-0.23 \mathrm{X}_{2}+3.034 \mathrm{X}_{3}-7.06$ $\mathrm{X}_{4}-1.11 \mathrm{X}_{5}$

Fruit damage $\mathrm{Y}=-568.99+6.56 \mathrm{X}_{1}+0.33 \mathrm{X}_{2}+4.9 \mathrm{X}_{3}-6.04$ $\mathrm{X}_{4}-0.21 \mathrm{X}_{5}$

$\mathrm{X}_{1}-$ Maximum temperature $\mathrm{X}_{2}-$ Minimum temperature

$\mathrm{X}_{3}$-Relative humidity $\mathrm{X}_{4}$-Sunshine hours $\mathrm{X}_{5}$-Rainfall

The regression equation indicated that an increase in $1 \%$ R. H. increased to range 3.03 and 4.9 of shoot damage and fruit damage per five plant. An increase of $1^{\circ} \mathrm{C}$ of maximum temperature would be lead to an increase of
4.27 and 6.56 of shoot damage and fruit damage/five plant/week. However, $1^{\circ} \mathrm{C}$ increase minimum temperature decreased the shoot damage of $E$. vittella by 0.23 /plant/week during rabi season.

Further, the values of coefficient of determination $\left(\mathrm{R}^{2}\right)$ indicated that there were $67.6 \%$ and $96.2 \%$ variation in $E$. vittella shoot damage and fruit damage was caused due to meteorological factors during the rabi 2017. These studies were in accordance with report of Pazhanisamy [12] in Spodoptera litura on groundnut.

Influence of weather parameters on per cent of shoot and fruit damage by $E$. vittella on bhendi during kharif 2017

Correlation between weather parameters and shoot and fruit damage of $E$. vittella in bhendi during kharif 2017 are presented in table 4 . The studies indicated that $\mathrm{R} . \mathrm{H}(\mathrm{r}=$ 0.231 and 0.241 ) excerted non significant negative association with per cent shoot damage and fruit damage of $E$. vittella respectively. Whereas rainfall $(\mathrm{r}=0.169$ and o.074) exhibited positive association with per cent of shoot damage and fruit damage. However minimum temperature ( $\mathrm{r}=-0.430$ and-0.309) showed negatively correlated with per cent of shoot damage and fruit damage and also sunshine hours negatively correlated with both shoot damage and fruit damage of $E$. vittella in bhendi during kharif 2017.

Similarly, Raju et al. [13] showed that fruit damage on number and weight basis were significantly negatively correlated with maximum temperature. The positive correlation was observed with morning and evening $\mathrm{RH}$ (o.88) and rainfall (0.82) [14].

Multiple regression equations were fitted for regression analysis between the weather parameter (X) and both the shoot damage and fruit damage on E. vittella in bhendi during the kharif season 2017.

\section{ParticularRegression equation}

Shoot damage $\mathrm{Y}=167.9+3.27 \mathrm{X}_{1}-1.53 \mathrm{X}_{2}+1.69 \mathrm{X}_{3}-2.50$ $\mathrm{X}_{4}-0.07 \mathrm{X}_{5}$

Fruit damage $\mathrm{Y}=226.9-2.90 \quad \mathrm{X}_{1}-1.47 \mathrm{X}_{2}+3.15 \mathrm{X}_{3}-0.188$ $\mathrm{X}_{4}-0.135 \mathrm{X}_{5}$

The regression equation indicated that an increase in $1 \%$ R. H. increased to range 1.69 and 3.15 of shoot damage and fruit damage per five plants. However $1^{\circ} \mathrm{C}$ increases minimum temperature decreased the shoot damage and fruit damage of $E$. vittella by 1.53 and $1.47 /$ five plants/week, whereas increases of $1^{\circ} \mathrm{C}$ of maximum temperature would be lead to an increase of 3.27 shoot damage/five plants/week, whereas decreased 2.29 fruit damage/five plants/week during kharif season 2017. Further, the values of coefficient of determination $\left(\mathrm{R}^{2}\right)$ indicated that there were $48.15 \%$ and $42.92 \%$ variation in $E$. vittella shoot damage and fruit damage was caused due to meteorological factors during the kharif 2017, respectively. These studies were in accordance with report of Pazhanisamy [12] in Spodoptera litura on groundnut. 
Table 1: Studies on incidence of $E$. vittella in bhendi ecosystem during rabi and kharif 2017

\begin{tabular}{|c|c|c|c|c|c|c|c|}
\hline \multirow[t]{3}{*}{ Month } & \multirow{3}{*}{$\begin{array}{l}\text { Std } \\
\text { week }\end{array}$} & \multicolumn{6}{|c|}{ Seasonal incidence of $E$. vittella during 2017} \\
\hline & & \multicolumn{2}{|c|}{ Rabi } & \multirow[t]{2}{*}{ Month } & \multirow{2}{*}{$\begin{array}{l}\text { Std } \\
\text { week }\end{array}$} & \multicolumn{2}{|l|}{ Kharif } \\
\hline & & $\begin{array}{l}\text { \% of shoot } \\
\text { damage }\end{array}$ & $\begin{array}{l}\text { \% of fruit } \\
\text { damage }\end{array}$ & & & $\begin{array}{l}\text { \% of shoot } \\
\text { damage }\end{array}$ & $\begin{array}{l}\text { \% of fruit } \\
\text { damage }\end{array}$ \\
\hline \multirow[t]{4}{*}{ Feb } & 5 & $\mathrm{O}$ & $\mathrm{O}$ & Sep & 36 & O & $\mathrm{O}$ \\
\hline & 6 & O & $\mathrm{O}$ & & 37 & $\mathrm{O}$ & $\mathrm{O}$ \\
\hline & 7 & 19.64 & $\mathrm{O}$ & & 38 & 12.5 & $\mathrm{O}$ \\
\hline & 8 & 18.33 & 16.67 & & 39 & 15.4 & 19.33 \\
\hline \multirow[t]{5}{*}{ Mar } & 9 & 28.63 & 19.44 & Oct & 40 & 26.85 & 21.75 \\
\hline & 10 & 37.1 & 42.04 & & 41 & 27.6 & 31.72 \\
\hline & 11 & 31.67 & $43 \cdot 33$ & & 42 & 32.98 & 42.1 \\
\hline & 12 & 34.27 & 36.48 & & 43 & 33.09 & 38.27 \\
\hline & 13 & 42.27 & 35.95 & & 44 & $29.5^{2}$ & 34.56 \\
\hline \multirow[t]{4}{*}{ April } & 14 & 38.66 & 41.11 & Nov & 45 & 24.76 & 32.47 \\
\hline & 15 & $37 \cdot 3$ & 44.47 & & 46 & 23.48 & 28.96 \\
\hline & 16 & 36.03 & 29.83 & & 47 & 15.4 & 27.3 \\
\hline & 17 & 19.84 & 32.78 & & 48 & 24.76 & 24.52 \\
\hline SEd & & 0.09 & 0.79 & & & 0.61 & 1.30 \\
\hline $\begin{array}{l}\mathrm{CD} \\
(0.01)\end{array}$ & & 0.27 & 2.23 & & & 1.68 & 3.62 \\
\hline
\end{tabular}

Mean of three replications, Date of sowing: 025.01.2017 (summer) and 05.09.2017, MSW-Meteorological Standard Week

Table 2: Correlation coefficients between weather parameters and weekly observed damage of $E$. vittella on bhendi during rabi season 2017

\begin{tabular}{lllllll}
\hline Season & $\begin{array}{l}\text { \% of shoot and fruit } \\
\text { damages }\end{array}$ & $\begin{array}{l}\text { Weather parameter } \\
\text { Max. temp. }\end{array}$ & $\begin{array}{l}\text { Min. Temp. } \\
{ }^{\circ} \mathbf{C}\end{array}$ & $\begin{array}{l}\text { RH } \\
\text { (\%) }\end{array}$ & Sunshine h & $\begin{array}{l}\text { Rainfall } \\
(\mathbf{m m})\end{array}$ \\
\hline Rabi 2017 & Shoot damage & $0.52^{*}$ & $0.629^{*}$ & -0.178 & $-0.566^{*}$ & 0.111 \\
& Fruit damage & $0.698^{*}$ & $0.748^{*}$ & -0.210 & $-0.641^{*}$ & 0.297 \\
Kharif 2017 & Shoot damage & -0.259 & -0.430 & 0.243 & -0.265 & 0.169 \\
& Fruit damage & 0.027 & -0.309 & 0.231 & -0.283 & 0.074 \\
\hline
\end{tabular}

${ }^{* *}$ Significant at 0.05 probability level, ${ }^{* *}$ Significant at 0.01 probability level

Table 3: Multiple linear regression analysis of $E$. vittella shoot damages (Y) and weather parameters (X) in bhendi during rabi season $2017 \cdot(n=13)$

\begin{tabular}{|c|c|c|c|c|}
\hline Variables & Partial regression coefficient & $\begin{array}{l}\text { Standard } \\
\text { error }\end{array}$ & 't' value & $\mathbf{r}^{2}$ \\
\hline \multicolumn{5}{|l|}{ Shoot damage } \\
\hline $\mathrm{X} 1=$ Max. Temperature & 4.272 & 2.36 & $1.81^{*}$ & \multirow{5}{*}{0.68} \\
\hline $\mathrm{X} 2=$ Mini. Temperature & -0.230 & 2.59 & $-0.08^{\mathrm{NS}}$ & \\
\hline $\mathrm{X}_{3}=$ Relative Humidity & 3.036 & 1.85 & $1.64^{*}$ & \\
\hline $\mathrm{X} 4=$ Wind speed & -7.060 & 4.93 & $-1.43^{*}$ & \\
\hline $\mathrm{X}_{5}=$ Rainfall & -1.105 & 1.10 & $-1.01^{*}$ & \\
\hline \multicolumn{5}{|l|}{ Fruit damage } \\
\hline $\mathrm{X} 1=$ Max. Temperature & 6.561 & 0.98 & $6.64^{*}$ & \multirow{5}{*}{0.96} \\
\hline $\mathrm{X} 2=$ Mini. Temperature & 0.344 & 1.08 & $0.32^{\mathrm{NS}}$ & \\
\hline $\mathrm{X}_{3}=$ Relative Humidity & 4.902 & 0.77 & $6.35^{*}$ & \\
\hline $\mathrm{X} 4=$ Wind speed & -6.041 & 2.06 & $-2.93^{*}$ & \\
\hline $\mathrm{X}_{5}=$ Rainfall & -0.213 & 0.46 & $-0.46^{\mathrm{NS}}$ & \\
\hline
\end{tabular}


Table 4: Multiple linear regression analysis of $E$. vittella fruit damages (Y) and weather parameters (X) in bhendi during kharif season $2017 \cdot(n=13)$

\begin{tabular}{|c|c|c|c|c|}
\hline Variables & Partial regression coefficient & $\begin{array}{l}\text { Standard } \\
\text { error }\end{array}$ & 't' value & $\mathbf{r}^{2}$ \\
\hline \multicolumn{5}{|l|}{ Shoot damage } \\
\hline $\mathrm{X} 1=$ Max. Temperature & 3.271 & 3.68 & $0.88 *$ & \multirow{5}{*}{0.48} \\
\hline $\mathrm{X} 2=$ Mini. Temperature & -15.373 & 7.17 & $-2.14^{* *}$ & \\
\hline $\mathrm{X}_{3}=$ Relative Humidity & 1.695 & 1.68 & $1.01^{*}$ & \\
\hline $\mathrm{X}_{4}=$ Wind speed & -2.502 & 2.68 & $-0.93^{*}$ & \\
\hline $\mathrm{X}_{5}=$ Rainfall & -0.067 & 0.06 & $-1.04^{*}$ & \\
\hline \multicolumn{5}{|l|}{ Fruit damage } \\
\hline $\mathrm{X} 1=$ Max. Temperature & -2.903 & 4.52 & $-0.64^{*}$ & \multirow{5}{*}{0.429} \\
\hline $\mathrm{X} 2=$ Mini. Temperature & -14.772 & 8.80 & $-1.67^{*}$ & \\
\hline $\mathrm{X}_{3}=$ Relative Humidity & 3.150 & 2.07 & $1.52^{*}$ & \\
\hline $\mathrm{X}_{4}=$ Wind speed & -0.188 & 3.29 & $-0.06^{\mathrm{NS}}$ & \\
\hline $\mathrm{X}_{5}=$ Rainfall & -0.135 & 0.08 & $-1.68^{*}$ & \\
\hline
\end{tabular}

$\mathrm{NS}=$ Non significant, ${ }^{*}$ significant $\mathrm{P}=0.05 \mathrm{CD}(\mathrm{P}=0.05)$ : 0.514

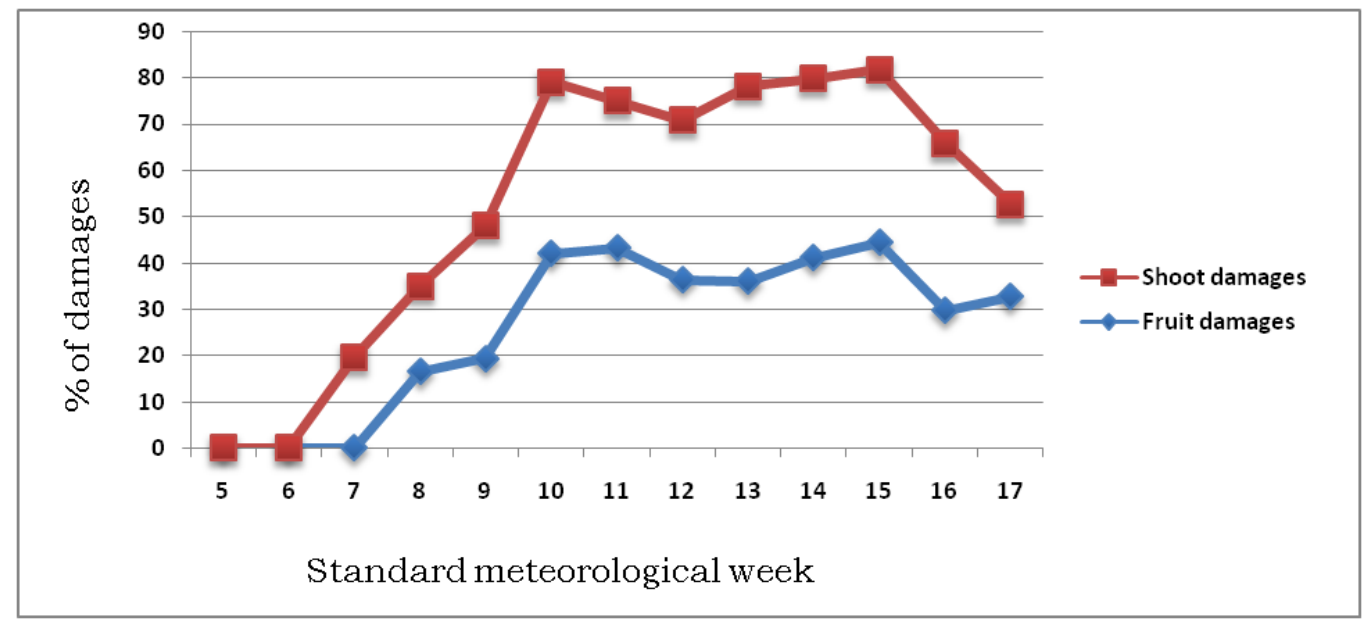

Fig. 1: Seasonal incidence of $E$. vittella on bhendi ecosystem during rabi season-2017

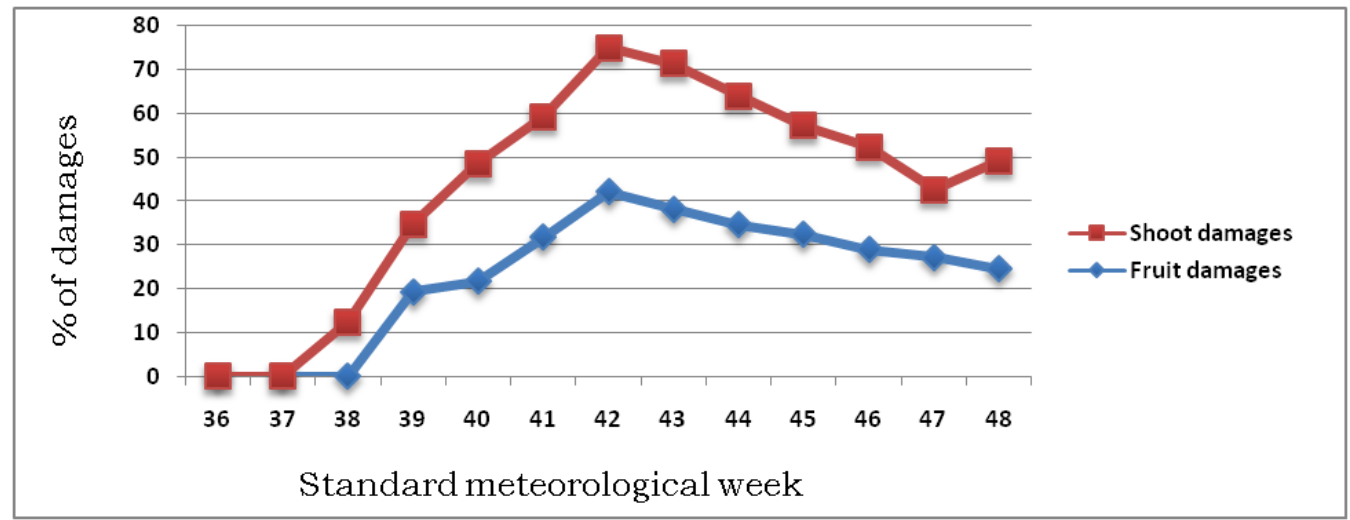

Fig. 2: Seasonal incidence of $E$. vittella on bhendi ecosystem during kharif season-2017

\section{REFERENCES}

1. Benchasri S. Okra (Abelmoschus esculentus (L.) Moench) as a valuable vegetable of the world. Ratarstvo i povrtarstvo. 2012;49:105-12.
2. FAO. Statistical Database. 2015. Retrieved from http://www. faostat. fao. org.

3. Anonymous. 2016. Horticulture-Statistical Year Book India 2016. Available at: http://www. mospi. gov. in/statistical-year-book-india/2016/178. 
4. Singh Y, Jha A, Verma S, Mishra VK, Singh SS. Population dynamics of sucking insect pests and its natural enemies on okra agro-ecosystem in Chitrakoot region. African Journal of Agricultural Research. 2013;8:3814-9.

5. Rai, A. B., Swamy, T. M. S., Kodandaram, M. H. and H. Jaideep. 2010. Integrated Pest Management of Vegetable Crops: Potential and Prospects. In: Souvenir of National Symposium on Conservation Horticulture held at Dehradun, Uttarakhand from 2123 March, 2010, pp. 246-261.

6. Malaichattiwar, Meena, R. S., Singh, P. S. and N. K. Yadav, 2014. Seasonal incidence of shoot and fruit borer (E. vittella) of Okra (Abelmoschus esculantus) in the Gangetic plains of Uttar Pradesh. Current Advances in Agricultural Sciences 6: 205-206.

7. Gomez, K. A. and Gomez, A. A. 1976. Statistical procedure for agricultural research, 2nd edition, John Wiley and Sons. Inc. New York.

8. Chouhan, S., Chandrakar, G., Nirala, Y. S. and N. Rana. 2016. Seasonal Incidence of Shoot and Fruit Borer, Earias vittella Fab. on Okra and their Correlation with Weather Parameters. Advances in Life Sciences 5: 419-421.

9. Shivashankara, T. N., 2012. Studies on bioecology and management of Okra fruit borers in the hill zone of
Karnataka. M. Sc. (Hort.) Thesis, Univ. Hort. Sci., Bagalkot, Karnataka (India). 232p.

10. Sharma, R. P., Swaminathan, R. and Bhati, K. K., 2010. Seasonal incidence of fruit and shoot borer of Okra along with climatic factors of Udaipur Region. Asian Journal of Agricultural Research, 4: 232-236.

11. Rajput, G. S. and Tayde, A. 2017. Population dynamics and comparative efficacy of certain novel insecticides, botanicals and bioagents, against shoot and fruit borer (Earias vitella Fabricius) of Okra crop. Journal of Entomology and Zoology Studies, 5: 1667-1670.

12. Pazhanisamy, M. 2015. Influence of certain ecofriendly approaches against Aproaerema modicella (Devender) and Spodoptera litura (Fabricius) on groundnut. Ph. D (Agri. Entomology) Thesis, Annamalai University, chidambaram. 275p.

13. Raju A, Reddy CN, Kumari DA. 2017. Seasonal incidence and correlation of abiotic factors against okra shoot and fruit borer. Contemporary Research in India 7:246-251

14. Sreedevi, K. V. 2011. Studies on insect pests of Okra, Abelmoschus esculentus (1.) with special reference to fruit borers and their management. M. Sc (Agri.) Thesis. University of Agricultural Sciences, Bangalore. 133p. 